\title{
The Use of Play and Inquiry in a Kindergarten Drama Centre: A Teacher's Critical Reflection
}

\author{
By: Laura Hope-Southcott
}

Laura Hope-Southcott is a $\mathrm{PhD}$ candidate in the joint $\mathrm{PhD}$ in educational studies program at Lakehead University, studying reflective practice and journal writing. She is also an early years teacher with the Lakehead Board of Education in Thunder Bay, Ontario. Email: csouthco@hotmail.com

The kindergarten drama centre is a place where children recreate familiar play scenarios, explore new ideas and feelings, and engage deeply in learning (Schwartz \& Copeland, 2010). Miller and Almon (2009) suggest that play is crucial to children's development. However, play is often contested as parents question its relevance at school (Ashiabi, 2007) and schools focus on academic achievement and readiness (Bodrova \& Leong, 2003; Miller \& Almon, 2009). This paper explores the author's learning through reflecting on the successes and challenges of a bakery centre created in her kindergarten classroom. The bakery became an excellent vehicle for strengthening students' literacy and motor skills through play, but the impact varied greatly across students in the class. Further, assessment and planning enhancements to the bakery were significantly restricted by constraints on the time and attention the author could devote to them due to the dynamic classroom environment. The bakery also led to a rethinking of the learning agenda in the classroom.

The drama centre is a staple in many kindergarten classrooms. It can be a place where children recreate familiar play scenarios as well as explore new ideas and feelings as they engage deeply in their learning (Schwartz \& Copeland, 2010). Children pretend to be moms, dads, doctors, fire fighters, chefs, and veterinarians while they are making breakfast, fighting fires, cooking, and caring for animals. Miller and Almon
(2009) suggest that play is critical to children's development in all learning domains and should be an essential part of the kindergartener's school day. However, the place of play is often contested as parents question its relevance at school (Ashiabi, 2007) and schools focus increasingly on academic achievement and school readiness (Bodrova \& Leong, 2003; Miller \& Almon, 2009). Wien (2008) puts it this way: "As pressures to teach literacy and numeracy have increased, it [becomes] difficult for teachers to notice what is outside their agendas" (p. 25). Pelletier (2011) views play as a vehicle for learning; for example, she connects play to literacy and numeracy development in the early years. To date, much of the literature on play focuses primarily on play's importance (Ashiabi, 2007; Bodrova \& Leong, 2003; Leong \& Bodrova, 2012) or provides resource ideas for teachers (Schwartz \& Copeland, 2010). In contrast, what we learn from teachers' classroom stories can add nuance to our current understandings of how play has the potential to extend learning in early years' classrooms and how teachers can support children's play, particularly in the kindergarten drama centre.

The purpose of this article is to critically reflect on how I used play in our drama centre bakery to extend learning. Inquiring into my own practice using a teacher research lens opens up a space in which to reflect on and unpack some of the successes and challenges I experienced as play at the bakery unfolded. I struggled at times to "notice what was outside of my agenda" (Wien, 2008, p. 25); I negotiated curricular goals with my kindergarten students and allowed them opportunities to plan, reflect, and set their own goals for learning through the drama centre bakery. Assumptions are that many of the practices for play and inquiry are already embedded in teachers' daily work in early years' classrooms. In contrast, some teachers struggle with the practical implications of the focus on play and inquiry as vehicles for learning (Stuber, 2007). Stuber (2007) points out that "today, it is rare to see elementary school classrooms with a plethora of materials that children can use in multiple ways depending on their individual learning styles, needs, and interests" (p. 2). According to Stuber, some teachers feel that play takes away from academic learning in the classroom. On the other hand, Helm, Beneke, and Steinheimer (2007) argue that, through play, children's interests and goals for their learning surface. Although there is a growing body of literature that supports play and inquiry-based learning, early years' teachers continue to explore the role of play and embed it in their daily practice (Ontario Ministry of Education, 2010).

\section{Significance of the Study}

Critical reflection can help teachers respond meaningfully to students while, at the same time, meeting the everyday challenges of teaching. The term critical is used in this context to refer to substantive and mindful thinking about teaching and learning as teachers examine what they do and say in the classroom from a variety of lenses aimed at improving practice. Teachers who are critically reflective seek ways to make changes in 
their classroom, school, and community and to use their practice as sites of critical reflection (Cochran-Smith \& Lytle, 2009; Goswami et al., 2009; Hatch et al., 2005). These teachers research their practice as a natural extension of their teaching and learning (Baumann, 1996). As teachers critically reflect, they dig deeper to better understand the assumptions, beliefs, and values that shape their practice.

Huerta-Charles (2007) puts forth that "[teachers] have not had the opportunity, nor the support, for critical thinking about their own practice"(p. 253). It is my belief that by hearing the experiences of other teachers, we become better at reflecting critically on our own actions to improve our practice. A better understanding, from a critical lens, of how dramatic play in the drama centre bakery extends young children's learning will add to the current conversation about the connections between play as a vehicle for learning, emergent curriculum, and the role of inquiry. Exploring the play that unfolded at the drama centre in my classroom opens up an opportunity to "rethink the concept of play" (Ontario Ministry of Education, 2010) opens up. This exploration of practice can also help illuminate how teachers plan for play to support the relationships children create with their peers, classroom materials, and the environment (Lewin-Benham, 2011).

\section{Theoretical Framework}

\section{Play and inquiry}

The literature in two key areas, playbased learning and inquiry, informs this reflection on my practice. In Ontario at the present moment, early learning programs are undergoing significant change in light of the Pascal report released in June 2009. Across the province, teachers, early childhood educators, and administrators are currently exploring how play can be used as a vehicle for learning in early years' classrooms.

Hughes (2003) defines play as the "freedom of personal choice, personal enjoyment, and focus on the activity rather than on its outcome" (cited in Saskatchewan Ministry of Education, 2008 , p. 24). Children choose or help to choose topics to explore, and it is their interests that determine the direction of learning. As Seitz (2006) puts it, "in negotiated or emergent curriculum, the child's interest becomes the key focus" (p. 1). Sometimes, children's conversations and natural curiosity are the catalyst for a new learning experience. Other times, a teacher or an early childhood educator invites children to discover a new material or an interesting object. Lewin-Benham (2006) suggests that working with emergent curriculum moves the focus of teaching and learning away from a set plan, including an agenda determined only by the teacher. She states: "Rather than sets of lesson plans and objectives, emergent curriculum is a process "teachers need to trust when planning for and creating learning experiences" (LewinBenham, 2006, p. 2). Following children's interests by observing them interact with each other, with the materials gathered for learning, and with the classroom environment reveals children's own agendas for learning.

\section{"As teachers critically reflect, they dig deeper to better understand the assumptions, beliefs, and values that shape their practice."}

By carefully listening to these cues, teachers can support children's own agendas and learning goals in all domains. Epstein (2003) contends that teachers must broaden the scope of skills they teach young learners, not focus solely on literacy and numeracy development. By listening with care, teachers are able to better understand children's interests and the learning goals they set for themselves (Wien, 2008). When teachers let go of their preset plans, they are free to tap into children's own agendas, trusting in the environment to act as a third teacher and in the children's interests to guide classroom learning (Lewin-Benham, 2006; Stuber, 2007). Wien (2008) argues that children's conversations reveal the depth and direction of their interests and goals. Themes, theories, and patterns surface during children's talk during play when we take the time to listen closely.

In this sense, the curriculum is fluid as both teachers and students negotiate learning. What are the children interested in learning more about? How do they want to show what they know? How do I proceed from this point? are some questions teachers ask themselves when they view children as capable learners and as co-constructors of learning experiences. Fraser (2012) writes: "Deconstructing our thinking about children and in collaboration with others constructs a view of children that is responsive to families, community, and culture of our time and place" ( $\mathrm{p}$. 33). To adopt a multiperspective view of learning or a poststructuralist view, teachers become open to new ways of understanding and viewing the children in their classroom (Fraser, 2012). One teacher suggests that "to become passionately engaged in learning, children have to feel free to choose where to invest their curiosity, intelligence, and emotions" (Wien, 2008, p. 119). Significant learning about a topic of children's interest can emerge through play when teachers listen carefully to children's conversations and connect their talk to curriculum. Although many definitions and characteristics of play as well as ways to spark play can be found in the literature, most authors agree that play is enjoyable, child-centred, and imaginative.

As defined in the literature, play encourages exploration, discovery, and creativity. New knowledge is constructed and consolidated as children engage deeply in play (Ashiabi, 2007; Millar Grant \& Eden, 2012) and inquiry (Millar Grant \& Eden, 2012; Schwartz \& Copeland, 2010; Youngquist \& Pataray-Ching, 2004). During play, children negotiate meaning, communicate with others, practice what they know, and add to each other's ideas. Millar Grant and Eden (2012) suggest that play is light hearted and happy. Children engaged in play laugh, talk, and learn joyfully with others in the classroom. 
Play is also supported by communication with peers and the teacher. Youngquist and Pataray-Ching (2004) and Stuber (2007) suggest that play helps children to reflect and critique the world around them if they are given time, resources, and space to "shift [their learning] to deeper levels of understanding" (Youngquist \& PatarayChing, 2004, p. 174). Children learn to be flexible in their thinking and to accept multiple points of view as they play.

Play is a complex and layered engagement involving all of the learning domains: social, cognitive, affective, communicative, and physical (Genishi \& Haas Dyson, 2009; Miller \& Almon, 2009; Youngquist \& Pataray-Ching, 2007). Children solve real-world problems during play, develop self-regulation, acquire numeracy and literacy skills, and work on fine and gross motor skills. In particular, drama can help "isolate, capture, and simulate increasingly abstract and complex concepts" (Wien, 2008 , p. 123) as children's play unfolds. As children play, they make sense of what they see, hear, and do. When teachers intentionally plan for and support learning through play, play has the potential to extend the thinking of our youngest learners. However, teachers also need to reflect on the play that is taking place in their classrooms to understand more fully how play scaffolds learning; they also need to reflect deeply on who is setting the learning agenda.

Lewin-Benham (2006) points out that "the curriculum emerges as children's investigations and activities [lead] to the evolution of old interests and the development of new ideas" (p. 5), thus preparing the classroom environment and documenting the children's experiences are important activities to support learning. Wien (2008) writes: "When young children are not used to making choices, I suspect the teacher needs to make explicit the potential in their choices and the successful outcomes that result from them" (p. 119), helping children set their own agenda and learning goals. When planning and reflection unfold as part of the learning process, young learners are digging deeper and applying what they know and can do (Epstein, 2003).

Play is important, but more structured learning takes place in kindergarten classrooms through play. Many learning experiences in a kindergarten classroom are sparked by and can help to support students' interests and natural curiosity. According to the Elementary Teachers' Federation of Ontario (2010a), inquiry incorporates four essential elements: initial engagement, exploration, investigation, and communication. Each of these elements leads children to question, notice, and observe the world around them. Worth and Chalaford (p. 19, 2010, cited in Elementary Teachers' Federation of Ontario, 2010a) argue that "direct hands-on exploration lies at the heart of inquiry and effective teachers design the learning environment to stimulate and support children's investigation." Children's wonderings and teachers' questions have the potential to act as "seeds" (Wien, 2008, p. 154) that, given the right conditions, help children's ideas grow. Teachers create space for children to test their own living theories in ways that make sense to them and that open up possibilities for new learning. They are mindful of the children's developing relationships with each other, with new and familiar materials, and with the classroom environment.

Katz (cited in Helm \& Katz, 2011) defines this type of learning in the following way: "A project is an in-depth investigation of a topic worth learning more about" (p. 1). Seitz (2006) agrees. She suggests that children learn best and are most engaged in the creation of new knowledge when they follow their curiosity, are invested in their learning, and set the learning agenda. Young students engaged in inquiry "find it interesting, enjoyable, and self-fulfilling" (Ontario Ministry of Education, 2011, p. 1) and are intrinsically motivated to learn. Inquiry supports children as they make decisions about what they want to learn and how they will demonstrate what they know. Children willingly spend their time, energy, and resources for learning when they are deeply engaged and intrinsically motivated. It is up to teachers to plan for and extend the relationships children develop with materials, the environment, and each other to support the potential of play and inquiry to produce rich learning that pushes children's thinking in new ways (Lewin-Benham, 2011).

\section{Methodology}

In this study, I inquired into my practice and my students' learning, drawing on teacher research and Anderson and Herr's (2005) action research spiral of plan/act/observe/ reflect. Hatch (2006) suggests that teacher research is an intentional and reflective study of questions that surface from a teacher's practice, explored to improve learning and to add to what we know about teaching and learning. Similarly, action research is an inward as well as an outward search embarked on by teachers for deeper understanding of a classroom event to bring about change (Anderson \& Herr, 2005; Zeichner \& Liston, 1996). Teacher research and action research are systematic ways to study teachers' identities, bring about generative change through reflective practice, and respond to local questions from the classroom (Samaras \& Freese, 2009). It is research "by me for us" (Samaras, 2011, p. 13). Understanding small classroom stories adds to what we know about teaching and learning one example at a time (CochranSmith \& Lytle, 2009; Hatch et al., 2005), creating a chain of stories that inform our daily work. Classroom stories develop as teachers work through a "cognitive knot" or puzzle from their practice (Wien, 2008).

Here, I reflect on and explore the small story that develops in my drama centre bakery to better understand how to extend learning through play. This small story becomes my own cognitive knot to unpack. In my classroom, the bakery became a space to rethink play in the drama centre and the role that play assumes in student learning and to create an opportunity to let children set the learning agenda. Following teacher research methodology, I used 
photos, anecdotal notes, observations, and work samples as multiple data sources. Documentation in the form of photos and observational notes helped me to reflect on the learning that was taking place in the drama centre bakery during play time. Wien (2008) suggests that such recording of insights on learning can help teachers communicate with students about their learning as well as reflect on what students know and can do. In turn, insights gained from observations and photos captured moments of learning used to plan for next steps. A new window on learning emerged.

\section{Classroom Context}

I teach in a large urban school in Ontario in a three-day-a-week senior kindergarten French immersion class. My school offers both a French immersion stream and an English stream to students from senior kindergarten to grade 8 . Both streams follow the Ontario curriculum; the key difference is the language of instruction. In the French immersion stream, the language of instruction in senior kindergarten and grade 1 is $100 \%$ French. Starting in grade 2, English is introduced into the school day. The ratio of English to French instruction continues to grow until students are instructed equally in both languages by grade 7 .

The majority of my kindergarten students are 4 and 5 years old and speak English as their first language. French immersion senior kindergarten is usually the children's first exposure to French. By winter break, many children have settled into our classroom routines and are beginning to use some French words and phrases to move about the day. The class size ranges yearly from 15 to 18 students with a mix of boys and girls.

I planned a bakery in our drama centre for several reasons. A bakery fit well with our literacy focus on the gingerbread man story and it tied in with plans to bake cookies. Story time is an important part of our day together at school, as it is in many kindergarten classes, and we bake once a month with a parent volunteer. I felt that a bakery offered a hands-on centre with many opportunities to interact with materials as well as provided students with multiple points of entry into play. Baking and cooking were also familiar activities for some children in the classroom.

I wanted to create a drama centre that incorporated children's prior knowledge to help scaffold our learning, while also recognizing that children come to school with different experiences and knowledges. Bodrova and Leong (2003) argue that "home and classroom experiences of many children may not be sufficient to produce the rich, imaginative play that has long been considered an inherent characteristic of early childhood" (p. 13). I wondered how the children's experiences with baking at home could shape our learning at the centre and what types of experiences would engage them in play at our drama centre bakery. A trip to a local store with a scratch bakery was organized to create a shared and focused experience (Schwartz \& Copeland, 2010), provide some prior knowledge of a bakery, and help students develop and use rich language related to a bake shop in order to deepen play. The drama centre bakery was open in the classroom for approximately one month.

\section{New Practices Emerge}

According to Wien (2008), new practices can emerge when teachers select a group of children to engage in inquiry, schedule play time during the school day, add different tools to the classroom environment, tease out meaning from children's wonderings, and encourage play. As I reflect on these key components in my own practice during the play at our drama centre bakery, I notice that new practices began to emerge and new learning unfolded for both my students and myself.

This is how new practice emerged in my classroom drama centre. At the bakery, different children engaged in play each day. Some children baked cookies and muffins while others took orders and delivered the treats. The aforementioned field trip gave students a shared experience and common language for their play at the bakery. Inquiry was incorporated into the bakery, such as when children were encouraged to explore new materials or create cookies to sell. Curricular expectations in literacy and numeracy were enriched by play at the drama centre as the children filled out order forms, explored patterning with the cookies, wrote their own and their classmates' names, and counted resources, such as buttons for decorating cookies. New materials were added to the centre to deepen and enhance the children's play scenarios at various points during the time the bakery drama centre was open; these included a storefront window, gingerbread-scented play dough, a cookie order form, and paper bags for delivery. Play was given a central focus in the day's schedule and planned for in the morning and the afternoon.

\section{Extending, supporting, enriching}

Once the bakery opened for business in our classroom, I wondered what else could be added to extend play, support inquiry, and enrich skills in language, math, and science. Leong and Bodrova (2012) posit that although play can help children learn to self-regulate, develop literacy and numeracy skills, and practice social skills, without adult guidance play's full potential may not be met. In addition, children need more than play experiences to gain skills in mathematics needed for later years, and although play has the potential to support numeracy skills, it does not "guarantee mathematical development" (Elementary Teachers' Federation of Ontario, 2010b, p. 29). Teachers need to plan play in a purposeful and mindful way, building on the children's mathematical understandings that surface while they play. Similar to Wien's (2008) notions of emergent curriculum mentioned earlier, Leong and Bodrova (2012) suggest five elements of play that teachers can scaffold in ways to support children's development in all the domains: planning; developing roles; using props; giving time; developing appropriate language; and negotiating settings. 
I used classroom observations to capture small moments of learning and to gather data. At-a-glance sheets were used to take notes during play time at the bakery. I recorded individual students' actions as well as student dialogue to reflect on after school. Observations and anecdotal notes taken at the bakery drama centre froze the learning so that I could study it more closely. As noted by the Saskatchewan Ministry of Education, (2008), "taking time to notice what children are saying, planning, and doing requires some organized way of observing and recording learning processes and information" (p. 36). Our play time lasted for approximately one hour each morning, plus an additional shorter block of time in the afternoon. Although ample time was scheduled for play to unfold during the day, it proved challenging to observe and take notes. Small groups of students would play at one time at the bakery. Children were free to choose which centre they wanted to play in and could move to a different centre freely. Sometimes, students from another centre came over to ask a question, while at other times I had to leave the bakery to attend to other students' needs. Most days, there were only short intervals without distractions or interruptions during which to gather information about students' learning.

\section{"When teachers let go of their preset plans, they are free to tap into children's own agendas, trusting in the environment to act as a third teacher and in the children's interests to guide classroom learning."}

When possible, I took notes about who played at the centre, what they were doing, and what they said in their conversations and peer interactions, filling in my at-aglance sheets. I used my observations to make changes in the bakery and tried to plan for next steps for individual students the following school day. Early on in the planning stages of the bakery, one idea that came from my observations of play in the classroom was to incorporate play dough at the centre, blurring boundaries between two centres. Previously, I had noticed that few students were visiting the play dough centre and I wondered how children could be encouraged to rediscover this material to strengthen their relationship with the materials in the classroom to support their learning.

Using play dough helps children to develop fine motor skills as they roll out the material, make large and small balls, and manipulate cutting tools. Play dough can also scaffold oral language development as students make meaning, negotiate rules, and communicate with one another through purposeful talk as they play. With the addition of play dough to the bakery drama centre, I hoped that the children would sell cookies, make cakes or muffins, and deliver goods to customers. I also hoped that the new material would encourage the children to talk to each other, supporting oral language growth and building fine motor skills as they made cookies to sell. When the play dough was added, I observed children talking about packaging and ingredients while they decorated the cookies and placed and took orders. I also noted that they were drawing on their experience at the local bakery, decorating cookies in a similar way to those they had seen at the store. The children also negotiated roles, such as who would bake and who would sell.

I placed new materials in the centre based on my daily observations of the children's play in the bakery, hoping to "stimulate investigation and learning" (Saskatchewan Ministry of Education, 2008, p. 25) through play and inquiry. Initially, rolling pins, cookie cutters, baking sheets, muffin tins, oven mitts, buttons, wooden cookies, and spatulas were organized in the centre. As the play evolved during the month, I wondered what other resources could be added to enrich and deepen the play. I drew from my observations made each day at the bakery. I observed that the children could benefit from additional practice in writing numbers and letters, and I searched for authentic ways to incorporate literacy and numeracy into the drama centre. As a result, I began to add materials to the centre to encourage writing and reading. By taking orders and reading them out to the baker, the children could practice and encourage the development of these skills in a real-life situation. Order forms for cookies as well as markers and bakery stationery were added.

Crosser (2008) suggests that teachers can extend thinking by asking questions, using prompts, and adding and removing materials to challenge students to think about different perspectives or a new way of working. In the case of the drama centre bakery, adding new materials did help to extend the children's play. Rather than taking orders verbally, children began to write down the names of their classmates and the number of cookies they ordered. A clothesline was soon erected in the centre for students to hang the completed order forms. A hanging curtain normally used for a puppet theatre was reconfigured into a storefront window and paper bags were used to deliver cookies. Children were using the new materials to support learning, set their own agendas, and build relationships.

\section{Saying, doing, representing}

The children represented their new learning in several ways. Initially, when I added a cookie order form to the centre, the children drew happy faces on the cookie outline. To provoke deeper thinking, I asked students in what other ways the form could be used. One day, I modelled how to use the form to record my cookie order. After modelling how to fill out the form, the children began to fill it out on their own and started to ask their classmates to write or spell their name and to list the type and number of cookies they wanted to purchase.

I found that the learning at the drama centre met students where they were by offering multiple entry points into the 
play. For instance, some students were ready to write and record numbers on the cookie order form. Other students were interested in making the cookies and began to roll the dough, strengthening their fine motor skills. Students also engaged in conversations about their play, supporting oral language development. The play at the drama centre offered a unique opportunity to use some of the language they had heard during their field trip to the local bakery. I also observed that some students needed assistance in negotiating rules, taking turns, and developing self-regulation. The bakery play scenario provided me with an opportunity to individualize some of the learning in my classroom.

\section{“.. listen more carefully to our students' conversations, be more flexible and open to new ideas, and embrace our own role of learner and co-constructor in the classroom."}

Although I felt I knew the curriculum well, I found that, at times, it was difficult to name some of the learning emerging in the bakery drama centre and connect it to curricular expectations for our kindergarten program. In hindsight, backmapping (Harvey \& Daniels, 2009) could have been beneficial in creating those crucial connections between the program's expectations and the learning that was unfolding in the classroom. This difficulty challenged me to think more deeply about who was setting the agenda for learning at the centre, what kind of relationships were being developed in our classroom, and how learning was enhanced or inhibited as children played at the bakery. Drawing on the work of Wien (2008) and Pelletier (2011), I reflected on how our kindergarten curriculum might potentially bump up against the children's own agendas and what that could mean for my own practice.

My daily observations and photos did help me to better understand some of the literacy and social skills that the children needed to work on further, such as letter and number formation as well as sharing. Perhaps these supports were more closely aligned with my own teacher's agenda and our program's curriculum than with the children's goals for learning.

\section{Critical Reflections}

Linder (2010) argues that teachers can assess children's learning when they have extensive time to reflect and observe children at play. Teachers' observations uncover the strategies children use to learn and highlight potential gaps in understanding. Wien (2008) describes the importance of slowing down the day, listening closely to children's conversations, and developing deep insights about learning in the classroom. When I let go of the teacher's agenda, the interests and goals of the children at the bakery had the potential to become the focus of learning. Children take ownership of their own learning when they are given choices and are empowered to make decisions (Stuber, 2007). These dynamics unfolded in some ways at the bakery.

Lewin-Benham (2011) suggests that it is the relationships children develop in the classroom that help or hinder deep learning. She asks: "How will this arrangement, that experience, those materials encourage children to form relationships with the space, the materials, with another child or a small group of children, with a teacher, a parent, with ideas between what they already know and something new" (p. 70)? The bakery fostered different relationships to support new learning and change practice. My students engaged in inquiry as they prepared ingredients, made cookies from play dough, and baked them in the oven, following their own interests and natural curiosity as they developed relationships with the materials and the environment. Although I offered the initial invitation to explore, the additional materials placed at the centre and direction of the play scenario were determined by the children, as were the peer interactions that unfolded. Using familiar materials in new ways helped to support the agenda set by the children and to give them opportunities to make their own decisions.

The children investigated the role of bakers and extended the initial play scenario when they used the storefront window to take orders and sell cookies. They also talked about delivering cookies to customers and shared their thinking around negotiated rules. Lewin-Benham (2011) states that the classroom environment can offer significant and meaningful possibilities for new and deeper understandings such as those offered at the bakery. The children were able to deepen their relationships with each other and the environment as they played at the bakery drama centre, taking up role playing based on their own prior knowledge, the shared experience of the field visit, and rules of play they had negotiated together.

Using the play at the bakery to assess learning has important implications for my classroom practice. Following Linder's (2010) approach, I assessed learning at the bakery by reflecting on writing samples, anecdotal notes, and photos. There were many challenges and successes during my daily assessments. I found it difficult to sustain my focus on the students at play in the bakery for extended periods of time. Because I was the only adult in the room, children from other centres often came to speak with me and other tasks in the classroom needed to be completed. At times, I felt that I only saw and understood the learning at a very superficial level and was not able to dig deeply enough to have a clear understanding of the relationships children were building with the environment and each other or to know what I could take from the play at the bakery to push their thinking further. Time limitations and distractions were challenges that frequently surfaced.

I also felt that I missed opportunities to extend the children's learning as I followed my own goals in our classroom bakery. My agenda focused on using the bakery as a way to scaffold literacy and numeracy skills. What were the other areas of 
learning outside my agenda that were left unattended? What did the children want to learn at the bakery? These are cognitive knots still waiting to be unravelled.

On the other hand, the bakery provided a meaningful context for children to practice their emerging social skills, and perhaps this area of development was more closely aligned to the children's agenda as they set rules, made sense of the bakery shop play, and communicated with each other. Self-regulation skills help children "recognize their strengths and needs and to monitor their progress, and adaptive, coping, and management skills help them to respond to challenges as they learn and develop" (Ontario Ministry of Education, 2011, p. 8). Play at the bakery helped children to self-regulate, the foundation of learning. Epstein (2003) argues that "when we engage children in planning, we encourage them to identify their goals and consider the options for achieving them" (p. 2). Providing time to reflect on their choices helps children to build on what they already know and can do as well as develop self-awareness.

Stuber (2007) argues that some learning centres are created with prescribed activities and time limits for children to accomplish during play. In contrast, our bakery allowed children the space to create their own play scenarios and choose the directions they wanted to follow. There were also multiple opportunities to play at the centre, allowing children time, space, and resources to recreate their play and practice skills. Although I had a literacy and numeracy agenda in mind when adding or removing materials or modelling, for example, the children were free to make decisions about how they used the materials, to negotiate roles and rules of the play, and to enter and reenter the play in "unhurried time" (Wien, 2008, p. 148).

Another challenge emerged when children chose a different centre, moved to a new centre to engage in play, or did not visit the bakery at all. Few children consistently played in the centre day after day. As a result, I felt that my observations on any particular day were only a small indication of the learning taking place rather than robust evidence of learning. It was difficult to see patterns emerging, notice new trends, or discover gaps in learning because the children often moved to a new centre or groups of children who played at the bakery one day chose to spend their time at the blocks or the paint easel the next day. Often my attention was required in other areas of the classroom to sharpen pencils, retrieve materials, or to help solve problems. It became challenging to plan individual next steps, and many of the interventions were targeted more at enhancing the children's relationships with the classroom environment and the new and familiar materials on offer at the drama centre in general. At times, it was also difficult to name the learning that was taking place and to fully understand what I observed, particularly when it was outside my own agenda.

Those children who returned more consistently to the bakery made use of the new resources and used them to extend their learning. The children who wrote their names and the number and type of cookie on the order forms, for example, were already engaged in many other reading and writing activities throughout the school day. These students naturally gravitated toward these types of learning experiences. The bakery did, though, offer an authentic and meaningful opportunity to practice their developing skills. New resources, such as the cookie form, storefront window, and clothesline, added a new dimension and complexity to some children's play and served to spark new interest for others. Some children began to take, read, and fill orders and deliver cookies. They made packages of cookies similar to those they had seen during our field trip and talked about making all the cookies uniform. Other students who may have benefited from more literacy or numeracy opportunities did not choose the centre at all during the month, even with encouragement. These students stayed at familiar centres in the classroom.

\section{Conclusion}

As my experience with the drama centre bakery shows, connecting play, inquiry, and learning can be problematic at times for teachers. Youngquist and PatarayChing (2004) encourage teachers to "create inquiry curricula around students' interests ... [that] help children broaden the ways in which they think, question, and explore" (p. 178). Although I agree that inquiry through play has the potential to help extend and push students' thinking in many different domains, it is challenging to assess and plan for individual learning. In contrast, the addition of new materials, teacher guidance and modelling, and a shared experience facilitated children's engagement in their play and supported the view of the classroom environment as a third teacher at the bakery. I found that the next steps for the centre that I planned were more general in nature than based on particular children's needs and focused mainly on the relationship children had with the classroom environment and materials. This may also be a result of my own growing understanding as a teacher of how to use play at the drama centre as a vehicle for learning.

I found it challenging to name some of the learning that was occurring at the drama centre and to observe what was needed for individual children's next steps based on that learning. Time and interruptions were also factors because our classroom is a three-day-a-week program. Perhaps this difficulty may be of less concern in a fullday every-day program where students are engaged in play for longer blocks of time and more often during the week, as some kindergartens in Ontario have begun to implement. Full-day every-day programs also have an early childhood educator in the room in addition to the teacher.

While assessment and planning next steps proved to be a challenge at the bakery centre, the centre provided an excellent venue for developing children's skills. Not all the children were ready for these tasks, so the gains were not uniform. My critical reflection throughout the bakery 
time helped me to identify these strengths and weaknesses and to reflect on my own practice and agenda setting. Teachers assume a significant role in planning an environment and organizing learning experiences that support and emphasize both play and inquiry in the early years classroom. In fact, this shift in focus requires us to listen more carefully to our students' conversations, be more flexible and open to new ideas, and embrace our own role of learner and co-constructor in the classroom. Although teachers may be "letting go," a phrase frequently heard in our daily work, they are still, as Wien (2008) notes, integral to the learning that unfolds through play and inquiry in the classroom.

\section{References}

Anderson, G., \& Herr, K. (2005). The action research dissertation: A guide for students and faculty. Thousand Oaks, CA: Sage.

Ashiabi, G. (2007). Play in the pre-school classroom: Its socioemotional significance and the teacher's role in play. Early Childhood Education Journal, 35(2), 199-207.

Baumann, J.F. (1996). Conflict or compatibility in classroom inquiry? One teacher's struggle to balance teaching and research. [Electronic Version]. Educational Researcher, 25(7), 29-36.

Bodrova, E., \& Leong, D. (2003). The importance of being playful. Educational Leadership, 60(7), 50-53. Retrieved from: http://prek.spps.org/uploads/ importanceofplayful.pdf

Cochran-Smith, M., \& Lytle, S. (2009). Inquiry as stance: Practitioner research for the next generation. New York, NY: Teachers College Press.

Crosser, S. (2008). Making the most of sand play. Earlychildhood NEWS. Retrieved from: http://www. earlychildhoodnews.com/

Elementary Teachers' Federation of Ontario (ETFO). (2010a). Thinking it through: Teaching and learning in the kindergarten classroom science and technology. Toronto, ON: Author.

Elementary Teachers' Federation of Ontario (ETFO). (2010b). Thinking it through: Thinking mathematically. Toronto, ON: Author.
Epstein, A. (2003). How planning and reflection develop young children's thinking skills. Beyond the Journal, Young Children on the Web, September, 1-8.

Fraser, S. (2012). Authentic childhood: Experiencing Reggio Emilia in the classroom (3rd ed.). Toronto, ON Nelson Education.

Genishi, C., \& Haas Dyson, A. (2009). Children, language and literacy: Diverse learners in diverse times. New York, NY: Teachers College Press.

Goswami, D., Ceci, L., Rutherford, M. \& Waff, D. (2009). On teacher inquiry: Approaches to language and literacy research. New York and London: Teachers College Press.

Harvey, S., \& Daniels, H. (2009). Collaboration and comprehension: Inquiry circles in action. Portsmouth, NH.: Heinemann.

Hatch, T. (2006). Teacher research: Questions for teacher educators. Retrieved from: www.journal.naeyc.org/

Hatch, T., Ahmed, D., Lieberman, A., Faigenbaum, D., White, M., \& Mace, D. (Eds.). (2005). Going public with our teaching: An anthology of practice. New York, NY: Teachers College Press.

Helm, J. H., Beneke, S., \& Steinheimer, K. (2007). Windows on learning: Documenting young children's work (2nd Ed). New York: Teachers College Press.

Helm, J. H., \& Katz, L. (2011). Young investigators: The project approach in the early years. New York: Teachers College Press.

Huerta-Charles, L. (2007). Pedagogy of testimony: Reflections on the pedagogy of critical pedagogy. In $\mathrm{P}$. McLaren \& J. L. Kincheloe (Eds.), Critical pedagogy: Where are we now (pp. 249-262)? New York, NY Peter Lang.

Leong, D., \& Bodrova, E. (2012). Assessing an scaffolding make-believe play. Young Children, January, 28-34.

Lewin-Benham, A. (2006). One teacher, 20 preschoolers, and a goldfish: Environmental awareness, emergent curriculum, and documentation. Beyond the Journal, Young Children on the Web, March, 1-7.

Lewin-Benham, A. (2011). Twelve best practices for early childhood education: Integrating Reggio and other inspired approaches. New York, NY: Teachers College Press.

Linder, S. (2010). A lesson planning model. Teaching Children Mathematics, November, 249-256.

Millar Grant, J., \& Eden, S. (2012, Winter). Engaging primary learners through play: The importance of play. ETFO Voice, 14(2), 21-24.
Miller, E., \& Almon, J. (2009). Crisis in kindergarten: Why children need to play in school. Alliance for Childhood, March, 1-8.

Ontario Ministry of Education. (2010). Kindergarten matters: Intentional play-based learning. Retrieved from: http://resources.curriculum.org/secretariat/ kindergarten

Ontario Ministry of Education. (2011, October). Getting started with student inquiry. Capacity Building Series. Special Edition \#24. Retrieved from: http://www.ontla. on.ca/library/repository/mon/26007/318849.pdf

Pelletier, J. (2011, October). Supporting early language and literacy. What Works? Research into Practice. Research Monograph \#37. Retrieved from: http:// www.edu.gov.on.ca/

Samaras, A. (2011). Self-study teacher research: Improving your practice through collaborative inquiry. Thousand Oaks, CA: Sage.

Samaras, A., \& Freese, A. (2009). Looking back and looking forward: An historical Overview of the Selfstudy school. In C. Lassonde, S. Galman, \& C. Kosnik (Eds.), Self-study research methodologies for teacher educators (pp. 3-21). Rotterdam, The Netherlands: Sense.

Saskatchewan Ministry of Education. (2008). Play and exploration: Early learning program guide. Regina, SK: Early Learning and Child Care Branch.

Schwartz, S., \& Copeland, S. (2010). Connecting emergent curriculum standards in the early childhood classroom: Strengthening content and teaching practice. New York, NY: Teachers College Press.

Seitz, H. (2006). The power of documentation in the early childhood classroom. [Electronic Version]. Young Children, March 2008, 88-93.

Stuber, G. (2007). Centring your classroom: Setting the stage for engaged learners. Beyond the Journal: Young Children, July, 1-3.

Wien, C.A. (Ed.). (2008). Emergent curriculum in the primary classroom: Interpreting the Reggio Emilia approach in schools. New York, NY: Teachers College Press.

Youngquist, J., \& Pataray-Ching, J. (2004). Revisiting "play": Analyzing and articulating acts of inquiry. Early Childhood Education Journal, 31(1), 171-178.

Zeichner, K., \& Liston, D. (1996). Reflective teaching: An introduction. New York, NY: Routledge. 